\title{
Invasive rodents and damages to food stocks: a study in the Autonomous Harbor of Cotonou, Benin
}

\author{
Henri-Joël Dossou ${ }^{(1,2)}$, Nestor Ahoyo Adjovi ${ }^{(3)}$, Gualbert Houéménou ${ }^{(2)}$, Thomas Bagan ${ }^{(4)}$, \\ Guy-Apollinaire Mensah ${ }^{(5)}$, Gauthier Dobigny ${ }^{(2,6)}$
}

\author{
(1) Département de Géographie et Aménagement du Territoire, Faculté des Lettres, Arts et Sciences humaines, Université \\ d'Abomey-Calavi, BP677, Cotonou (Bénin). E-mail: gauthier.dobigny@ird.fr \\ (2) Laboratoire de Recherche en Biologie Appliquée, École Polytechnique d'Abomey-Calavi, Université d'Abomey-Calavi, \\ 01 BP 2009, Cotonou (Bénin). \\ (3) Institut National de Recherche Agricole du Bénin, 01BP884, Cotonou (Bénin). \\ (4) Port Autonome de Cotonou, Département de Gestion de l'Environnement, 01 BP 927, Cotonou (Bénin). \\ ${ }^{(5)}$ Faculté des Sciences Agronomiques, Université d'Abomey-Calavi, 01 BP 526, Cotonou (Bénin). \\ (6) UMR CBGP (IRD, CIRAD, INRA, Montpellier SupAgro, MUSE), Montpellier (France).
}

Received 10 February 2019, accepted 13 November 2019, available online 17 December 2019.

This article is distributed under the terms and conditions of the CC-BY License (http://creativecommons.org/licenses/by/4.0)

Description of the subject. Rodents may be major pests to crops and stored food, thus threatening food security. Among them, invasive species such as rats and mice are of particular concern since they are disseminated globally following international trade. We investigated the small mammal assemblage within the international seaport of Cotonou, Benin, in order to determine the relative importance and distribution of native $v s$ invasive rodent species, as well as to evaluate the amount and associated costs of rodent-induced damages on imported/exported stored goods (here, rice).

Objectives. Description of rodent assemblages within an African seaport, and evaluation of the associated damages on stored food stocks.

Method. Rodent communities were described following trapping results while associated damages and costs were evaluated following a 25 days-long monitoring campaign and subsequent economic estimation of loss.

Results. Our results show that invasive mice and rats are, from far, the most impacting rodents in the storage warehouses, and that the associated economic losses are quite large. Moreover, we point towards a few environmental management procedures that may greatly reduce the impact of rodents on stored goods.

Conclusions. Damages and costs due to invasive rodents within the Cotonou Harbor are so that they justify financial investment in rodent population control.

Keywords. Stored products, rodent control, food security, economic losses, international trade, Rattus, Africa.

\section{Rongeurs invasifs et dégâts sur les denrées stockées : une étude dans le Port Autonome de Cotonou, Bénin}

Description du sujet. Les rongeurs sont des ravageurs majeurs des denrées stockées et constituent, de ce fait, une véritable menace pour la sécurité alimentaire. C'est particulièrement vrai des espèces envahissantes comme les rats et les souris qui se sont disséminés à travers toute la planète à la faveur du commerce international. Nous avons étudié les communautés de petits mammifères du port international de Cotonou, Bénin, afin de déterminer l'abondance relative des rongeurs invasifs et des natifs, et pour évaluer la quantité et les couts associés aux dégâts causés par les rongeurs sur les denrées stockées importées/ exportées (du riz pour notre étude).

Objectifs. La description des communautés de rongeurs dans un port africain et l'évaluation des dégâts sur les denrées stockées. Méthode. Les communautés de rongeurs ont été décrites par des séances de piégeage, tandis que les dégâts et les couts associés ont été évalués par une campagne de surveillance de 25 jours et des inférences économiques.

Résultats. Nos résultats montrent que les rats et les souris sont de loin les espèces les plus nuisibles dans les entrepôts de stockage, et que les pertes associées sont très élevées. De plus, nous identifions différentes procédures qui pourraient diminuer significativement l'impact de ces espèces sur les denrées alimentaires importées au port.

Conclusions. Dans le port de Cotonou, les dégâts dus aux rongeurs et les couts associés sont tels qu'ils justifient amplement des investissements financiers pour le contrôle des populations de rongeurs.

Mots-clés. Denrées entreposées, lutte antirongeur, sécurité alimentaire, pertes économiques, commerce international, Rattus, Afrique. 


\section{INTRODUCTION}

Some rodent species are highly prolific and show a large ecological plasticity that allows them to colonize a wide range of habitats. In particular, rodents can be numerous in agro-ecosystems where their abundance and diet (which often includes seeds, fruits and/or plants) make them important pests for crops and stored foods (Leirs, 2003). As such, rodents are major contributors to food insecurity (Drummond, 2001; Meerburg et al., 2009; Singleton et al., 2010). As an example, the Norway (Rattus norvegicus) and black ( $R$. rattus) rats are thought to be responsible for the destruction of $5-10 \%$ of rice annual harvest in Asia, thus representing a loss equivalent of food for 180 million people (Singleton, 2003). In the United States, economic losses attributed to rat-induced damages to stored grains may reach 19 million USD each year (Pimentel et al., 2000). Data in Africa are scarce and usually focus on damages in fields (e.g., Hopf et al., 1976; Gautun, 1999; Békélé et al., 2003; Mulungu et al., 2003). For instance, in Tanzania, the impact of the multi-mammate rat Mastomys natalensis was estimated to lead to an annual 5-15\% loss of the national maize production (i.e., 60 million USD; Makundi et al., 1999; Skonhoft et al., 2006, and references therein). Damages to domestic stocks are also thought to be quite high in the Sahel region; unfortunately, only indirect and usually non-quantitative data are available (e.g., Garba et al., 2014). In Benin, some surveys were conducted on food storage conditions and post-harvest losses of stored grains (Affognon et al., 2000; Fandohan, 2000; Arouna et al., 2011; Togola et al., 2013). However, to our knowledge, studies on rodent-induced damages to store food and associated economic consequences in the urban and industrial environments are inexistent. Yet, any rodent control policy should rely on an initial quantitative assessment of damages and corresponding costs in order to be accurately calibrated (i.e., control cost should be much lower than damages cost). This is the reason why we got interested in rodent-induced damages on stored food within the Autonomous Harbor of Cotonou (AHC), Benin.

The AHC was created at the end of the $19^{\text {th }}$ century, but quickly grew following various extension plans during the $20^{\text {th }}$ century (Janin, 1964). It now represents a stepping-stone of the national economy that counts for $15 \%$ of the Benin gross national product (PAC, 2013) and $90 \%$ of legal exchanges with foreign countries in Europe, Asia, North and South America (SOBEMAP, 2015). It also represented the main maritime entry point for West African hinterland countries such as Burkina Faso and Niger. Between 2006 and 2012, 14,746 ships have stopped in Cotonou. In average, 2.4 and 0.08 million of tons of imported and exported goods transit annually through the AHC, respectively (2013-2015 data; SOBEMAP, 2015).
Rattus norvegicus, $R$. rattus and Mus musculus are the most invasive rodent species on the planet. They were disseminated throughout the world following human migrations and international trade, especially maritime exchanges (Aplin et al., 2011; Bonhomme et al., 2011; Song et al., 2014). This had and still has major consequences in terms of zoonotic agents dispersal (ex. Yersinia pestis, hantavirus, etc; Lin et al., 2012; Voger et al., 2013; see Kosoy et al., 2015; Schmid et al., 2015) as well as the destruction of food items (Pimentel et al., 2000; Singleton, 2003; de Groot, 2004). Rats and mice as well as their associated ectoparasites and rodent-borne pathogens are usually abundant in large ships from which they may be involuntary introduced into seaports and subsequently colonize new areas (Harper \& Bunbury, 2015, and references therein; Harimalala et al., 2017; Kuo et al., 2017; Rahelinirina et al., 2018). We here focus on the AHC rodent community in order to:

- assess the presence of native $v s$ invasive species;

- to evaluate the potential impact of rodents on stored

food within this major West African harbor.

\section{MATERIALS AND METHODS}

\subsection{Small mammals trapping}

Cotonou is the economic capital city of Benin and lies along the Guinea Gulf on the West African Atlantic coast. The Autonomous Harbor of Cotonou is located in the core city (between latitude $6.341 \mathrm{~N}$ and 6.351 $\mathrm{N}$, and longitude $2.409 \mathrm{E}$ and $2.435 \mathrm{E}$ ). Permit to work within the seaport was obtained from the seaport authorities (see Acknowledgements). Trapping was performed in eleven sites (Table 1 and Figure 1) within the AHC using 20 locally-made wire mesh traps during three consecutive nights in each site (i.e. 60 night-traps per site, hence 660 night-traps in total). Baits consisted of fried fish gills as previously shown to be efficient (e.g., Dossou et al., 2015; Houéménou et al., 2019). Field campaigns were organized four months after the last poisoning campaign that are regularly conducted by the AHC Environment Department in charge with rodent control. Trapping sites (warehouses, outdoor restaurants, second hand car parks, docks, fresh fish market, fresh fish storing site, truck mechanical workshop, construction site; Table 1 and Figure 1) were selected following habitat representativeness as well as the access authorization, signs of rodent presence (feces, holes, footprints and/ or spoors) and traps' security. Administrative offices could not be sampled due to restricted access. When captured, rodents were brought alive in the lab in order to be sacrificed using di-ethyl-ether. None of the species investigated in the present study has protected 
Tableau 1. Summary of trapping efforts and captures in the 11 trapping sites within the Autonomous Harbor of Cotonou, Benin - Résumé des efforts et des résultats de capture dans les 11 sites de piégeage au sein du Port Autonome de Cotonou, Bénin.

\begin{tabular}{|c|c|c|c|c|c|c|c|}
\hline \multirow[t]{2}{*}{ Site } & \multirow{2}{*}{$\begin{array}{l}\text { Trapping } \\
\text { effort }\end{array}$} & \multicolumn{6}{|c|}{ Trapping success } \\
\hline & & Total (\%) & $\begin{array}{l}\text { Crocidura } \\
\text { cf. olivieri }\end{array}$ & $\begin{array}{l}\text { Mastomys } \\
\text { cf. natalensis }\end{array}$ & $\begin{array}{l}\text { Mus } \\
\text { musculus }\end{array}$ & $\begin{array}{l}\text { Rattus } \\
\text { norvegicus }\end{array}$ & $\begin{array}{l}\text { Ratttus } \\
\text { rattus }\end{array}$ \\
\hline Warehouse 1 (wh1) & 60 & $13(21.7)$ & 0 & 1 & 1 & 11 & 0 \\
\hline Warehouse 2 (wh2) & 60 & $11(18.3)$ & 0 & 0 & 5 & 6 & 0 \\
\hline Warehouse 3 (wh3) & 60 & $14(23.3)$ & 0 & 0 & 0 & 14 & 0 \\
\hline Warehouse 4 (wh4) & 60 & $9(15)$ & 0 & 0 & 0 & 9 & 0 \\
\hline Outdoor restaurants & 60 & $23(38.3)$ & 0 & 0 & 0 & 21 & 2 \\
\hline Docks & 60 & $31(51.7)$ & 27 & 0 & 0 & 3 & 1 \\
\hline Fresh fish market & 60 & $37(61.7)$ & 24 & 0 & 0 & 13 & 0 \\
\hline Fresh storing fish site & 60 & $45(75)$ & 19 & 1 & 0 & 0 & 25 \\
\hline Truck mechanical workshop & 60 & $26(43.3)$ & 2 & 0 & 0 & 19 & 5 \\
\hline Construction site & 60 & $2(3.3)$ & 0 & 0 & 0 & 2 & 0 \\
\hline Second hand car parks & 60 & $2(3.3)$ & 0 & 0 & 0 & 2 & 0 \\
\hline Autonomous Harbor of Cotonou & 660 & $213(32.3)$ & 72 & 2 & 6 & 100 & 33 \\
\hline
\end{tabular}

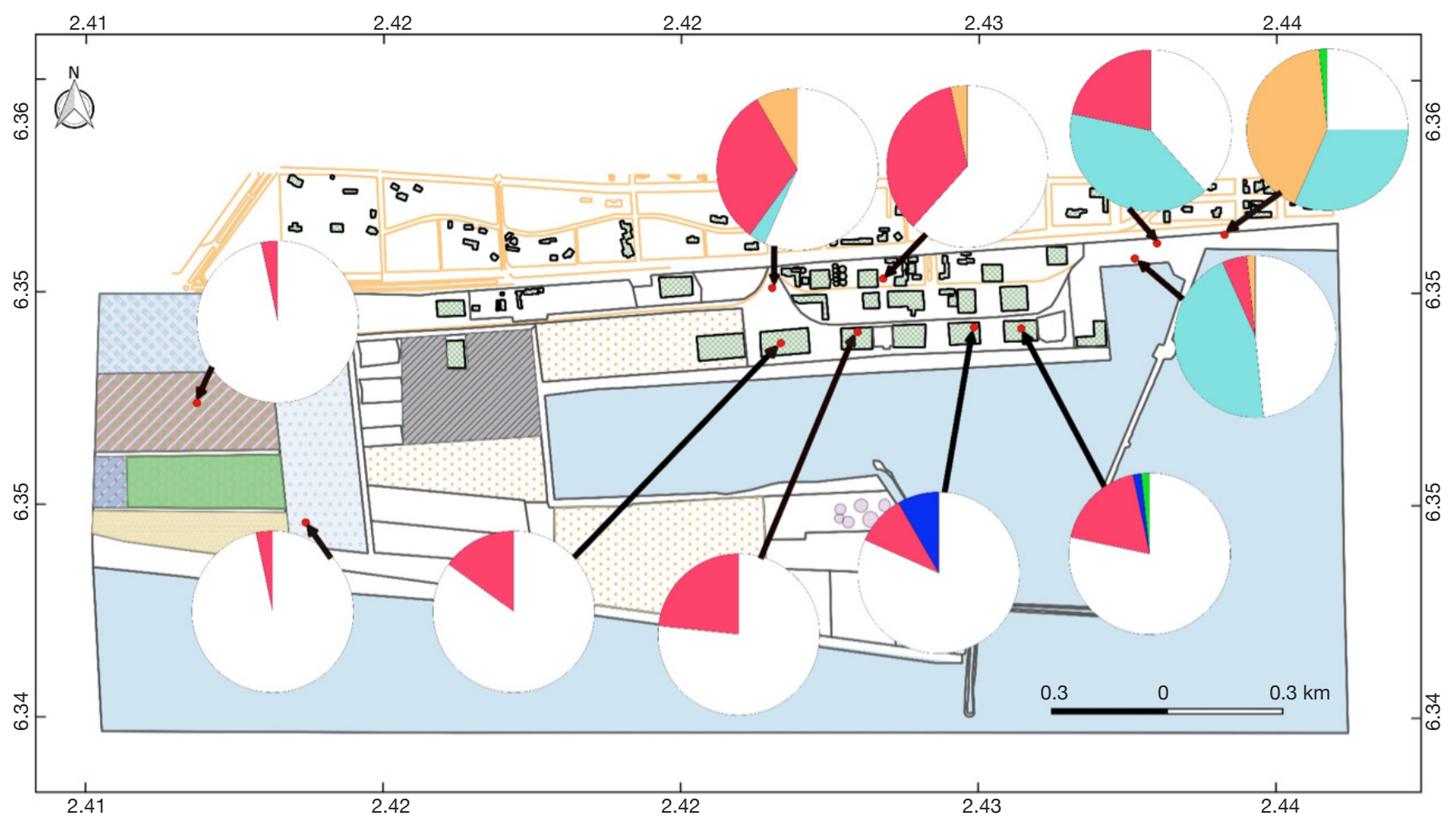

Figure 1. Harbor map showing trapping sites and results - Carte du port indiquant les sites et les résultats de capture.

Each color represents a small mammal species: pink, light and dark blue, green and orange for Rattus norvegicus, R. rattus, Mus musculus, Mastomys natalensis and Crocidura cf. olivieri, respectively - Chaque couleur représente une espèce de petit mammifère : le rose, le bleu clair, le bleu foncé, le vert et l'orange correspondent respectivement à Rattus norvegicus, R. rattus, Mus musculus, Mastomys natalensis et Crocidura $c f$. olivieri. 
status (see IUCN and CITES lists). All animals were treated in a humane manner following the guidelines of the American Society of Mammalogists (Sikes et al., 2011). Species identification was performed on morphological and external measurements grounds (De Visser et al., 2001).

\subsection{Assessment of rodent damages}

Four dock warehouses $(120 \times 80 \mathrm{~m})$, all located in AHC zone 1, were selected for the evaluation of rodent-induced economic loss due to damages to stored food. Three of them were public infrastructures (warehouses wh1, wh2 and wh3; Figure 1), with poor light and floors covered with cotton and rice wastes (see Figure 2). Rodent dead bodies were visible and rodent feces were numerous. In these buildings, rice bags were stacked on pallets, thus leaving a space between the floor and the goods piling as well as between wooden boards of the pallets. Piles are up to $7 \mathrm{~m}$ high and located around $1 \mathrm{~m}$ away from the walls. The fourth warehouse (wh4) was managed by a private company and looked cleaner, with less waste and no

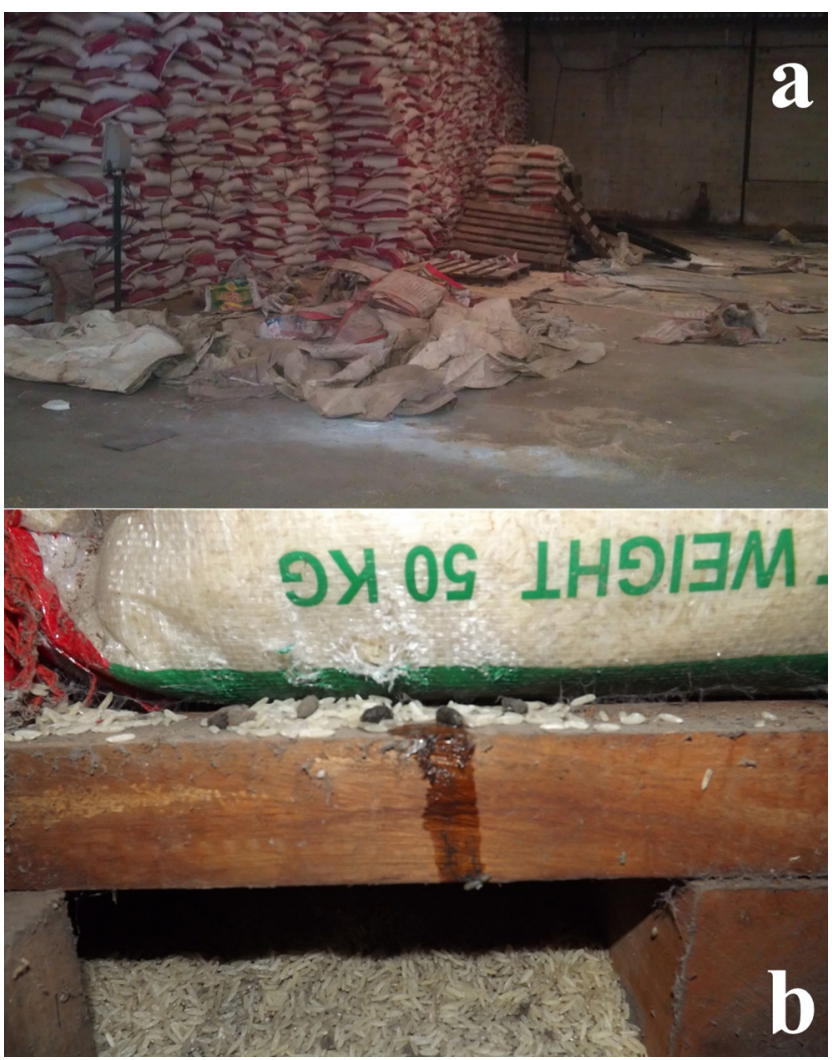

Figure 2. Images de l'intérieur des entrepôts du Port Autonome de Cotonou avec (a) des piles de sacs de riz, (b) du riz jonchant le sol et des fèces et de l'urine de rongeurs Pictures of inside Cotonou seaport storehouses showing (a) rice bags piles, $(\boldsymbol{b})$ wasted rice on the floor as well as rodent urine and feces. rodent dead bodies visible. Rice bags were stacked on a plastic sheet lying directly on the floor, and they were tightly packed with almost no space between them.

All four warehouses were monitored during 25 days (from $7^{\text {th }}$ March to $1^{\text {st }}$ April 2016, dry season). During the whole period of our survey, only imported $50 \mathrm{~kg}$ rice bags were stored in the investigated warehouses. All bags were intact at the beginning of our survey and were systematically counted on the first day. Stocks were re-quantified each day when goods removal operations were conducted by the harbor operators, something which occurred 3-5 times in each warehouse within our 25 day-long study. Each time, both removed and remaining rice bags were counted and individually checked in order to assess the exact number of rice bags that were damaged by rodents. The implication of rodents was notified when the tear line was not located along a seam, when it was irregular, when teeth marks were visible and/or when feces or urine was observed on the tear line or below it (on the bag or the floor). It should be noted that the operators systematically remove the rice bags that are damaged by the handling process, thus limiting the risk of confusion between handling- and rodentinduced damages.

In addition to the count and check of rodent-induced damages on rice bags after each removal operations, we also performed a systematic examination of removed and remaining bags in order to count those that were contaminated either by rodents feces or urine, or by dead animals. When contamination by urine was suspected, it was systematically verified through direct smelling.

Finally, our observations were completed by interviews of the warehouse operators in order to learn about their perception of rodent-induced damages as well as stocks management and rodent control procedures.

\subsection{Evaluation of economic losses associated with rodent-induced damages}

Economic losses associated with rodent-induced damages were estimated from the amount of rice bags that were destroyed or contaminated in the four warehouses during our 25 days-long survey. However, while contaminated bags were systematically destroyed by the AHC staff, teared ones were sometimes reconditioned into new bags. As such, we had to take into account the number of reconditioned rice bags (NRRB) which was provided to us for each warehouse by the AHC staff. From there, the final number of lost rice bags was:

$$
\mathrm{FNLRB}=\mathrm{NCRB}+(\mathrm{NIDRB}-\mathrm{NRRB})
$$


where NCRB and NIDRB correspond to the numbers of contaminated and initially destroyed rice bags, respectively.

The associated costs of these different types of rice bag losses were calculated using the unitary price (UP) of a $50 \mathrm{~kg}$ rice bag (17,500 Francs CFA or $26.72 €$ ), of a new empty bag (NB; 300 Francs CFA or $0.46 €)$ as well as the flat rate of the labor in charge of reconditioning (FRL; 100,000 Francs CFA or $152.67 €$ for a complete work session). These values were provided by AHC services during our survey (March 2016) and allowed us to calculate:

- the cost of rice bag destruction:

$$
\mathrm{CRBD}=(\mathrm{NIDRB}-\mathrm{NRRB}) \times \mathrm{UP} \text {, }
$$

- the cost of rice bag contamination:

$\mathrm{CRBC}=\mathrm{NCRB} \times \mathrm{UP}$,

- the cost of rice reconditioning:

$$
\mathrm{CRR}=(\mathrm{NRRB} \times \mathrm{NB})+\mathrm{FRL} .
$$

The total cost of rodent-induced damages to rice bags was equal to the sum of these three independent costs, i.e. $\mathrm{TC}=\mathrm{CRBD}+\mathrm{CRBC}+\mathrm{CRR}$.

\section{RESULTS}

\subsection{Small mammals within the AHC}

In total, 213 small mammals were trapped over the 11 sites within the AHC (Table 1; total trap success of $32.3 \%$ ). Among them, 141 were rodents, with $100 R$.norvegicus, $33 R$.rattus, 6 M.musculus and 2 Mastomys sp. The 72 remaining individuals were shrews that we referred to as Crocidura cf. olivieri on morphological records.

Norway rats ( $R$. norvegicus) were present in all sites within the AHC, and were found especially numerous in all warehouses investigated. Shrews were also found in many habitats (i.e. docks, fresh fish market, outdoor restaurants, fresh fish storing site and truck mechanical workshop), as were black rats ( $R$. rattus) (docks, outdoor restaurants and fresh fish storing site). Multi-mammate rats (M.natalensis) were captured in one warehouse (wh1) and the fresh fish storing site. The six house mice (M. musculus) were all found in warehouses.

In the four warehouses that were investigated for rodent-induced damages, we found mainly $R$. norvegicus ( $85.1 \%$ of captures in these four sites) as well as a few house mice (12.8\%) and one M.natalensis $(2.1 \%)$.

\subsection{Rodent-induced damages and associated costs}

Interviews of AHC operators and our own observations strongly suggest that most rodent-induced damages mainly occur in the warehouses where food stocks are stored. In addition, two main categories of damages could be clearly identified and consisted in food containers (essentially bags) and food stocks destruction on the one hand, and goods contamination by urine and feces on the other hand.

The 25 day-long monitoring of $50 \mathrm{~kg}$ rice bags that were stored in four warehouses showed that rodentinduced damages were quite elevated (Table 2). In total, $565(10.9 \%)$ out of the 6,164 bags initially stored in these four warehouses have undergone damages by small mammals. This represents 28.25 tons of rice lost (out of the 308.2 initial tons) in a bit more than three weeks. However, these damages were variable between warehouses, ranging from 47 to 222 bags, which represent $2.4 \%$ to $15.8 \%$ of the total stocks in each warehouse.

Costs associated with the rodent-induced damages (Table 2) ranged from 939,600 to 4,019,200 Francs CFA (from 1,435 to $6,136 €$ ) per warehouse, thus reaching a total of $10,442,000$ Francs CFA or 15,942 $€$ for the four warehouses during the 25 day-long period of study.

\section{DISCUSSION}

The small mammals assemblage observed in the AHC is characterized by four rodent and one shrew species, namely: $R$. norvegicus, $R$. rattus, Mastomys sp., M. musculus and $C$. cf. olivieri. Sibling and sometimes sympatric Mastomys sp. coexist in West Africa (Dobigny et al., 2008; Granjon \& Duplantier, 2009), including in Benin (Capanna et al., 1996; Codjia et al., 1996). However, Mastomys natalensis is one of the most typical commensal one (Granjon \& Duplantier, 2009) and unpublished cytochrome b sequencing data strongly suggest that Mastomys individuals captured in Cotonou core city all belong to M. natalensis (Tatard et al., unpublished data). This is the reason why, awaiting for further cytogenetic and/or DNA-based analyses, we here provisionally referred the AHC multi-mammate rats as to $M$. cf. natalensis. In the same manner, species-specific taxonomic identifications may be difficult in the Crocidura genus. This is the reason why shrews from the AHC were only provisionally referred to as $C$. cf. olivieri at that stage.

Among the five species identified in Cotonou harbor, two are native $(M$. natalensis and the shrew $C$. cf. olivieri) and three are invasive (R.rattus, $R$.norvegicus and $M$.musculus). The presence of the invasive house mice, Norway and black rats is not unexpected in a seaport, but studies on their finescale respective distributions within a harbor are not so numerous. Here, we found that $R$. norvegicus were 


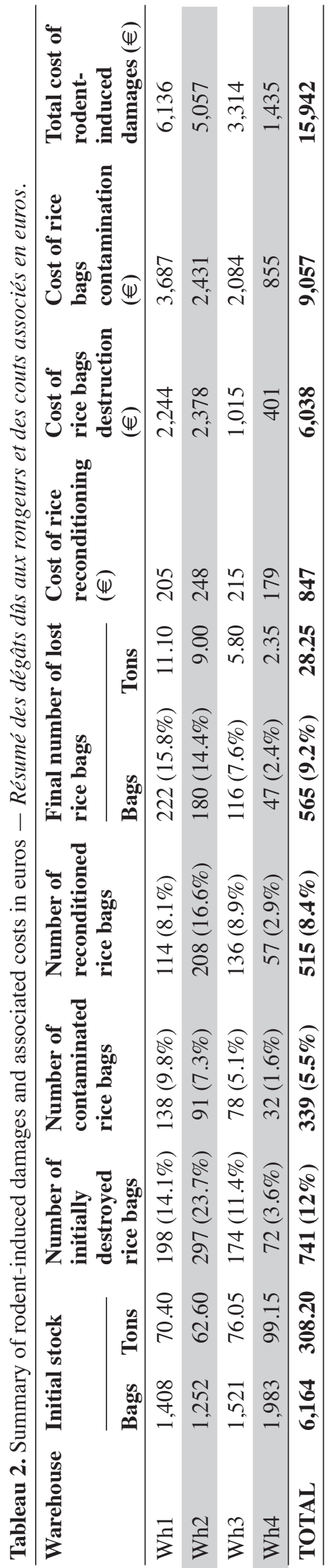

abundant in most habitats $(\mathrm{n}=100)$, but particularly within the warehouses where they represent the bulk of rodent captures (Table 1). More surprisingly, $R$. rattus was not so frequent $(\mathrm{n}=33)$ and was mostly observed in peripheral areas of the harbor (Table 1). Strikingly, it was absent from warehouses where it may suffer from competitive exclusion by Norway rats. That strongly differs from what was observed in Cotonou and in its neighborhoods where black rats appear as the most abundant and widespread commensal rodent species while Norway rats were much less represented (Dossou et al., 2015; Houéménou et al., 2019). House mice were relatively rarely trapped in the AHC ( $\mathrm{n}=$ 6; Table 1). However, the use of only locally made wire-mesh traps may greatly biased our results since this small-sized species is known to be difficult to trap using this type of trap (Garba et al., 2014; Dalecky et al., 2015). As a consequence, the use of more adapted traps (such as Sherman ones) will be required to have a clearer picture of the abundance and distribution of Mus domesticus in Cotonou harbor that seems to be able to coexist with Norway rats in the AHC warehouses, as supported by the frequent direct observations of living mice in these buildings. More convincingly, we found that the native $M$. natalensis was quite rare $(\mathrm{n}=2$; Table 1). This may also be true, though not as marked, in the rest of the city where it was found to be much less numerous than rats in anthropized habitats (Dossou et al., 2015; Houéménou et al., 2019). This may be explained by the competitive exclusion of M. natalensis by invasive species such as Rattus species, as this may also be the case elsewhere in West Africa (e.g., Niamey, Niger: Garba et al., 2014). However, such a native-to-invasive species turnover remains to be demonstrated, especially in the longterm, as are the potential underlying processes at work (Garba et al., 2014). Finally, shrews were found in four AHC habitats where they were actually quite abundant $(n=72)$, even when coexisting with other rodent species such as the Norway rat (Table 1). Shrews have a strictly insectivorous diet and, in that sense, they may not be direct competitors of rats or mice in anthropized habitats where the latter species may rather feed on human food stocks and remains. This may be particularly true in harbor warehouses where $R$. norvegicus and $M$. domesticus most probably rely on grains stocks to survive, while shrews most probably hunt insects that are themselves attracted by grains. However, such a speculative view of resources sharing between small mammal species in domestic habitat remains to be properly investigated.

Nevertheless, except maybe the impact of shrew urine, there is little doubt that only rodents are susceptible to induce important damages on food stocks within the AHC. The role of invasive rodents seems critical here. Indeed, essentially Norway rats 
were trapped in the warehouses where this quite large-sized species is unambiguously abundant, as confirmed by trapping data, our own observations of $R$. norvegicus dead bodies as well as AHC operators' interviews. Damages may be due to destructions and contamination of bags as well as direct food consumption. In addition, although we could not observe it ourselves, AHC workers testimonies suggest that destruction of bags may sometimes lead to the collapse of a whole bags stack, thus leading to massive losses in one time (de Groot, 2004). Yet, the most frequently observed rodent-induced damages correspond to contamination by small mammal urine and feces since any contamination sign leads to the systematic elimination of the whole bag from the commercial circuit, while bags that are only teared (i.e. without apparent contamination) are reconditioned. As such, rodents damage more than they consume, and it was already estimated that, for one consumed grain, 10-15 ones were unfit for human consumption (GISD, 2005).

Our survey highlighted very large food and economic losses due to rodents in the AHC since we estimated that almost $16,000 €$ were lost in the four warehouses during 25 days. A simple annual extrapolation leads to $58,400 €$ lost per warehouse each year. It should be noted that our estimates are indicative and that losses may greatly vary according to local and contextual conditions as well as the type of goods involved. They may also be an underestimation since we could not take into account the potential costs associated with public health expenses associated with possible undetected contamination of food stocks (Battersby, 2004). In addition, the impact of rodent gnawing on port infrastructures was not evaluated neither, while such damages were mentioned as important by the AHC authorities and could also be very expensive. As an example, between $18 \%$ and $26 \%$ of electric equipment in Boston, USA, were found to display signs of rodent presence (Colvin et al., 1998). Accordingly, American insurance companies believe that $25 \%$ of fires of unknown origin are in fact due to rodent activities (Battersby, 2004), thus representing a huge source of economic loss.

This is the reason why we believe that our results are a sufficient proof-of-concept to justify further actions towards a better monitoring and control of rodent populations in international seaports. However, control campaigns are not so easy to conduct since they may face at least two important problems. The first one consists in post-eradication reinvasion by rodents following constant propagule pressure (Abdelkrim et al., 2007; King et al., 2011; Savidge et al., 2012), something that may be particularly critical in harbors. The second one is the rapid evolution of resistance to anticoagulants which are the most widespread rodenticides used (Buckle, 2012; Oldenburg et al., 2014). In such a context, alternative methods, such as environmental maintenance, may be extremely useful. For instance, our data show that wh1, wh2 and wh3 undergo much more rodent-induced damages than wh4 where the layout of stocks presents interesting differences. Indeed, in the latter warehouse, rice bags are stacked on plastic sheets lying directly on the floor, and the piles are quite compact, thus decreasing the surface available for potential rat attacks and probably limiting the possibilities of rodent movements as well. Moreover, the systematic cleaning of warehouses' floors, especially after loading operations (which may induce bags tearing and grains flowing) would greatly limit the availability of food resources for rodents, hence their abundance. Finally, simple and costless rodent-proofing procedures are still to imagine in order to hinder access to stored goods by rodents.

\section{CONCLUSIONS}

Our survey provides a clear picture of small mammal assemblage within an African international seaport. Stored food warehouses are largely dominated by Norway rats and house mice which together cause important damages to imported/exported rice bags. The associated cost of these rodent-induced destructions are sufficiently elevated to justify financial investment in rodent control. We identified some simple aspects of warehouse management that, if applied, may significantly reduce rodent damages.

\section{Acknowledgements}

We are very grateful to the port authorities who allowed us to conduct field survey within the Autonomous Harbor of Cotonou ((authorization number 743/PAC/DG/DGA/SG/ DOMS/DGE/SEEP, $28^{\text {th }}$ march 2014; authorization number 692/PAC/DG/DGA/DRH/SEF and service memo 716/PAC/ DG/DGA/SG/DRH/SEF, $9^{\text {th }}$ october 2015). We are also very thankful to all AHC workers who accepted to answer our questions.

\section{Bibliography}

Abdelkrim J., Pascal M. \& Samadi S., 2007. Establishing causes of eradication failure based on genetics: case study of ship rat eradication in Ste. Anne archipelago. Conserv. Biol., 21, 719-730, doi.org/10.1111/j.15231739.2007.00696.x

Affognon H., Kossou D. \& Bell A., 2000. Développement participatif de technologies post-récolte au Bénin. Eschborn, Allemagne : GTZ.

Aplin K.P. et al., 2011. Multiple geographic origins of commensalism and complex dispersal history of black 
rats. PLoS ONE, 6, e26357, doi.org/10.1371/journal. pone. 0026357

Arouna A., Adégbola P.Y. \& Biaou G., 2011. Analyse des coûts de stockage et de conservation du maïs au SudBénin. Bull. Rech. Agron. Bénin, 2, 1-11.

Battersby S., 2004. Public health policy: can there be an economic imperative? An examination of one such issue. J. Environ. Health Res., 3, 19-28.

Bekele A., Leirs H. \& Verhagen R., 2003. Composition of rodents and damage estimates on maize farms at Ziway, Ethiopia. In: Singleton G.R. et al., eds. Rats, mice and people: rodent biology and management. Canberra, Australia: ACIAR, 262-263.

Bonhomme F. et al., 2011. Genetic differentiation of the house mouse around the Mediterranean basin: matrilineal footprints of early and late colonization. Philos. Trans. R. Soc. London, Ser. B, 278, 1034-1043, doi.org/10.1098/rspb.2010.1228

Buckle A., 2012. Anticoagulant resistance in the United Kingdom and a new guideline for the management of resistant infestations of Norway rats (Rattus norvegicus Berk.). Pest Manage. Sci., 69, 334-341, doi.org/10.1002/ps.3309

Capanna E., Codjia J.T.C., Chrysostome C. \& Civitelli M.V., 1996. Les chromosomes des rongeurs du Bénin (Afrique de l'ouest) : 3. Murinae. Rendiconti Lincei, 8, 25-37, doi.org/10.1007/bf03002251

Codjia J.T.C., Civitelli M.V., Bizzoco D. \& Capanna E., 1996. Les chromosomes de Mastomys natalensis et Mastomys erythroleucus (rongeurs, Muridés) du sud Bénin (Afrique de l'Ouest): nouvelles précisions sur la variabilité chromosomique. Biologie, 58, 185206.

Colvin B.A., Swift T.B. \& Fothergill F.E., 1998. Control of Norway rats in sewer and utility systems using pulsed baiting methods. In: Baker R.O. \& Crabb A.C. Proceedings of the $18^{\text {th }}$ Vertebrate Pest Conference, March 2-5, 1998, Costa Mesa, California, 247-253. Davis, CA, USA: University of California, doi. org $/ 10.5070 / \mathrm{v} 418110082$

Dalecky A. et al., 2015. Range expansion of the invasive house mouse Mus musculus domesticus in Senegal, West Africa: a synthesis of trapping data over three decades, 1983-2014. Mammal Rev., 45, 176-190, doi. org/10.1111/mam.12043

de Groot I., 2004. Protection des céréales et des légumineuses stockées. Wageningen, Pays-Bas: Fondation Agromisa, 1-23.

De Visser J., Mensah G.A., Codjia J.T.C. \& BokononGanta A.H., 2001. Guide préliminaire de reconnaissance des rongeurs du Bénin. Cotonou: Réseau Rongeurs et Environnement; Nijmegen, Pays-Bas: Vereniging voor Zoogdierkunde en Zoogdierbescherming.

Dobigny G. et al., 2008. An update on the taxonomy and geographic distribution of the cryptic species Mastomys kollmannspergeri (Muridae, Murinae) using combined cytogenetic and molecular data. J.Zool., 276, 368-374, doi.org/10.1111/j.1469-7998.2008.00500.x

Dossou D.K., Houémènou G., Tenté B . \& Mensah G.A., 2015. Inventaire des rongeurs et de leurs ectoparasites en milieu urbain au Bénin : transmission possible de zoonoses. Ann. Sci. Agron., 19, 545-574.

Drummond B.C., 2001. Rodents and biodeterioration. Int. Biodeterior. Biodegrad., 48, 105-111, doi.org/10.1016/ s0964-8305(01)00073-7

Fandohan P., 2000. Introduction du grenier fermé en terre au Sud-Bénin pour le stockage du maïs. Porto-Novo: Rapport INRAB/PTAA.

Garba M. et al., 2014. Spatial segregation between invasive and native commensal rodents in an urban environment: a case study in Niamey, Niger. PLoS ONE, 9, e110666, doi.org/10.1371/journal.pone. 0110666

Gautun J.C., 1999. Les rongeurs nuisibles aux cultures et aux denrées stockées. Rapport technique, Centre Régional Agrhymet. Niamey, Niger : DFPV.

GISD (Global Invasive Species Database), 2005. GISD (Global Invasive Species Database), http://www.issg. org/database/species/ecology. asp?si=159\&fr=sts=ss

Granjon L. \& Duplantier J.M., 2009. Les rongeurs de l'Afrique sahélo-soudanienne. Marseille, France: Éditions IRD.

Harimalala M. et al., 2017. Genetic structure and gene flow of the flea Xenopsylla cheopis in Madagascar and Mayotte. Parasites Vectors, 10, 347, doi: 10.1186/ s13071-017-2290-6

Harper G.A. \& Bunbury N., 2015. Invasive rats on tropical islands: their population biology and impacts on native species. Global Ecol. Conserv., 3, 607-627, doi. org/10.1016/j.gecco.2015.02.010

Hopf H.S., Morley G.E. \& Humphries J.E., eds, 1976. Rodent damage to growing crops and to farm and village storage in tropical and subtropical regions. London: Ministry of Overseas Development.

Houéménou G. et al.., 2019. Pathogenic Leptospira in commensal small mammals from the extensively urbanized coastal Benin. Urban Sci., 3(99), doi:10.3390/ urbansci3030099

Janin B., 1964. Le nouveau port de Cotonou. Rev. Géogr. Alpine, 52, 701-712, doi.org/10.3406/rga.1964.3192

King C.M. et al., 2011. Reinvasion by ship rats (Rattus rattus) of forest fragments after eradication. Biol. Invasions, 13, 2391-2408, doi.org/10.1007/s10530-0110051-6

Kosoy M., Khlysap L., Cosson J.F. \& Morand S., 2015. Aboriginal and invasive rats of genus Rattus as hosts of infectious agents. Vector-Borne Zoonotic Dis., 15, 3-12, doi.org/10.1089/vbz.2014.1629

Kuo C.C. et al., 2017. Significance of major international seaports in the distribution of murine typhus in Taiwan. PLoS Negl. Trop. Dis., 11, e0005430, doi.org/10.1371/ journal.pntd.0005430 
Leirs H., 2003. Management of rodents in crops: the pied piper and his orchestra. In: Singleton G.R., Hinds L.A., Krebs C.I. \& Spratt D.M., eds. Rats, mice and people: rodent biology and management. Canberra, Australia: ACIAR, 183-190.

Lin X.D. et al., 2012. Migration of Norway rats resulted in the worldwide distribution of Seoul Hantavirus today. J. Virol., 86, 972-981, doi.org/10.1128/jvi.00725-11

Makundi R.H., Oguge N.O. \& Mwanjabe P.S., 1999. Rodent pest management in East Africa: an ecological approach. In: Singleton G.R., Hinds L.A., Leirs L. \& Zhang Z., eds. Ecologically-based rodent management. Canberra, Australia: ACIAR, 460-476.

Meerburg B., Singleton G.R. \& Leirs H., 2009. The year of the rat ends: time to fight hunger! Pest Manage. Sci., 65, 351-352, doi.org/10.1002/ps.1718

Mulungu L.S. et al., 2003. The rodent density-damage function in maize fields at an early growth stage. In: Singleton G.R., Hinds L.A., Krebs C.J. \& Spratt D.M., eds. Rats, mice and people: rodent biology and management. Canberra, Australia: ACIAR, 301-303.

Oldenburg J. et al., 2014. Comparative genetics of warfarin resistance. Hamostaseologie, 34, 143-159, doi. org/10.5482/hamo-13-09-0047

PAC (Port Autonome de Cotonou), 2013. Rapport final de l'étude sur l'élaboration de la politique environnementale du port de Cotonou et du programme de gestion environnementale pour le port de Cotonou. Impact Consultants, 10-49.

Pimentel D., Lach L., Zuniga R. \& Morrison D., 2000. Environmental and economic costs of non-indigenous species in the United States. BioScience, 50, 53-65, doi. org/10.1641/0006-3568(2000)050[0053:eaecon]2.3.co;2

Rahelinirina S. et al., 2018. Risk of maritime introduction of plague from Madagascar to Mayotte. Acta Tropica, 187, 140-143, doi.org/10.1016/j.actatropica.2018.07.029

Savidge J.A. et al., 2012. Genetic evaluation of an attempted Rattus rattus eradication on Congo Cay, U.S. Virgin
Islands, identifies importance of eradication units. Biol. Invasions, 14, 2343-2354, doi.org/10.1007/s10530-0120233-X

Schmid B.V. et al., 2015. Climate-driven introduction of the Black Death and successive plague reintroductions into Europe. Proc. Natl. Acad. Sci. U.S.A., 112, 3020-3025, doi.org/10.1073/pnas.1412887112

Sikes R.S. \& Gannon W.L., 2011. Animal care and use committee of the American Society of Mammalogists: guidelines of the American Society of Mammalogists for the use of wild mammals in research. J. Mammal., 92, 235-253.

Singleton G., 2003. Impacts of rodents on rice production in Asia. IRRI Disc. Paper Series, 45, 1-30.

Singleton G. et al., 2010. Impacts of rodent outbreaks on food security in Asia. Wildl. Res., 37, 355-359, doi. org/10.1071/wr10084

Skonhoft A. et al., 2006. The bioeconomics of controlling an African rodent pest species. Environ. Dev. Econ., 11, 453-475, doi.org/10.1017/s 1355770x06003044

SOBEMAP (Société Béninoise de Manutention Portuaire), 2015. Service des statistiques et études économiques: relevés statistiques. Cotonou, Bénin : SOBEMAP.

Song Y., Lan Z. \& Kohn M.H., 2014. Mitochondrial DNA phylogeography of the Norway rat. PLoS ONE, 9, e88425, doi.org/10.1371/journal.pone.0088425

Togola P.A. et al., 2013. Economic losses from insect pest infestation on rice stored on-farm in Benin. J. Appl. Sci., 13, 278-285, doi.org/10.3923/jas.2013.278.285

Vogler A.J. et al., 2013. A decade of plague in Mahajanga, Madagascar: insights into the global maritime spread of pandemic plague. mBio, 4, e00623-12, doi.org/10.1128/ mbio.00623-12

(49 réf.) 